\title{
Brief review of the Azygophleps legraini Yakovlev et Saldaitis, 2011 species group (Lepidoptera: Cossidae: Zeuzerinae) with descriptions of three new species from western Africa
}

\section{Краткая ревизия группы видов Azygopbleps legraini Yakovlev et Saldaitis, 2011 (Lepidoptera: Cossidae: Zeuzerinae) с описанием трех новых видов из Западной Африки}

\author{
R.V. Yakovlev ${ }^{1,2}$, Gy. M. László ${ }^{3}$, G.C. Müller ${ }^{4,5}$, V.D. Kravchenko 6

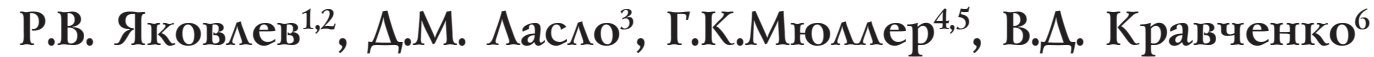

\footnotetext{
${ }^{1}$ Altai State University, pr. Lenina 61, Barnaul, 656049, Russia. E-mail: yakovlev_asu@mail.ru

${ }^{2}$ Tomsk State University, Laboratory of Biodiversity and Ecology, Lenina pr. 36, 634050 Tomsk, Russia. E-mail: yakovlev_asu@mail.ru ${ }^{3}$ African Natural History Research Trust, Leominster, Street Court, Kingsland, Herefordshire, HR6 9QA, G.B. E-mail: gyula@anhrt.org.uk ${ }^{4}$ Department of Parasitology, Kuvin Center for the Study of Infectious and Tropical Diseases, The Hebrew University Hadassah Medical School, Jerusalem, Israel. E-mail: guntercmuller@hotmail.com

${ }^{5}$ Faculty of Medicine, Pharmacy and Odontostomatology, Malaria Research and Training Center, University of Sciences, Technique and Technology of Bamako, Mali.

${ }^{6}$ Department of Zoology, George S. Wise Faculty of Life Sciences, Tel Aviv University, Tel Aviv 69978, Israel. E-mail: vasiliy@post.tau.ac.il

${ }^{1}$ Алтайский государственный университет, пр. Ленина 61, Барнаул 656049, Россия.

2 Томский государственный университет, Лаборатория биоразнообразия и экологии, пр. Ленина 33, Томск, 634050 Россия.
}

KEY WORDS: entomology, Lepidoptera, Carpenter moths, Zeuzerinae, fauna, Africa, taxonomy.

КЛЮЧЕВЫЕ СЛОВА: энтомология, Lepidoptera, древоточцы, Zeuzerinae, фауна, Африка, таксономия.

ABSTRACT. The article contains the descriptions of three new species: Azygophleps adamsonae Yakovlev et László, sp.n. (type locality: Cameroon, North Region, Wack (La Falaise), Azygophleps attenboroughi Yakovlev, Müller et Kravchenko, sp.n. (type locality: Southern Mali, 80 km SW Bamako, near Kineiroba, river Niger), and Azygophleps pinheyi Yakovlev et László, sp.n. (type locality: Muquitixe, Angola). The descriptions are provided with detailed diagnoses and illustrations.

РЕЗЮМЕ. В статье описано три новых вида Azygophleps adamsonae Yakovlev et László, sp.n. (типовая местность: Cameroon, North Region, Wack (La Falaise)), Azygophleps attenboroughi Yakovlev, Müller et Kravchenko, sp.n. (типовая местность: Southern Mali, 80 km SW Bamako, near Kineiroba, river Niger), и Azygophleps pinheyi Yakovlev et László, sp.n. (типовая местность: Muquitixe, Angola). Описания сопровождаются подробным диагнозом и проиллюстрированы.
Introduction

Carpenter-Moths (Cossidae) are a relatively large family of ditrise Lepidoptera, including over thousand taxa [Nieukerken et al., 2011]. Cossidae of Africa are still insufficiently studied. The most well studied subfamily is Zeuzerinae, where several genera have recently been revised: Acosma Yakovlev, 2011 (type species, by monotypy - Acosma gurkoi Yakovlev, 2011), Tarsozeuzera Schoorl, 1990 (type species, by original designation - Zeuzera kochi Semper, 1896-1902), Paralophonotus Schoorl, 1990 (type species, by monotypy Zeuzera auroguttata Herrich-Schäffer, 1854), Pseudozeuzera Schoorl, 1990 (type species, by monotypy — Duomitus biatra Hampson, 1910), Alophonotus Schoorl, 1990 (type species, by monotypy — Chalcidica (Duomitus) rauana Strand, 1909), and Eburgemellus Schoorl, 1990 (type species, by monotypy - Xyleutes geminatus Gaede, 1930) [Schoorl, 1990; Yakovlev, Witt, 2017a, 2018a-c; Yakovlev et al., 2018; Yakovlev, 2019]. Detailed distributional data of the taxa of the

How to cite this article: Yakovlev R.V., László Gy.M., Müller G.C., Kravchenko V.D. 2020. Brief review of the Azygophleps legraini Yakovlev et Saldaitis, 2011 species group (Lepidoptera: Cossidae: Zeuzerinae) with descriptions of three new species from western Africa // Russian Entomol. J. Vol.29. No.3. P.289-294. doi: 10.15298/rusentj.29.3.08 
subfamily are provided for only a few countries: South Africa, Namibia, Botswana [Mey, 2015, 2016, 2017, 2019]; Swaziland [Yakovlev, Witt, 2016a], Zambia [Yakovlev, 2014], Zimbabwe [Yakovlev, Lenz, 2013], Malawi [Yakovlev, Murphy, 2013] and Angola [Yakovlev et al., 2019].

One of the largest and poorly known African Zeuzerinae genera is Azygophleps Hampson, 1892 (type species, by monotypy - Hepialis scalaris Fabricius, 1775). According to the Catalog of Cossidae in the Old World [Yakovlev, 2011] the genus includes 29 valid species. Later, several new species were described from eastern and southern Africa, and several new synonyms and new combinations were established [Yakovlev, Witt, 2016b, 2017b; Mey, 2016, 2017, 2019; Yakovlev, 2019]. The species of the genus are widely distributed in the Paleotropics and in the southern Palaearctic (Turkey, Iran, Afghanistan, Pakistan, South China) [Daniel, 1963, 1964; Arora, 1976; Hua et al., 1990; Yakovlev, 2011; Yakovlev, Dubatolov, 2013; Yakovlev et al., 2015].

In 2011, A. legraini Yakovlev et Saldaitis, 2011 (Figs 1-4, 9, 13) was described from a single specimen, from Cameroon (type locality: Adamaoua, nr. Ngaoundéré, Ngaoundaba). The species is characterized by its very small size and lemon-yellow color of the wings. Later, several specimens of this rare species have been found in the collections of the Royal Museum of Central Africa and the African Natural History Research Trust from Cameroon and Congo. Further three, similar species have also been found from Mali, Angola and Cameroon, all clearly differing from $A$. legraini externally as well as in the male genitalia structures. The descriptions of these three new species are given below.

\section{Material and methods}

Adults of Cossidae were collected using light traps. Male genitalia were dissected and mounted in euparal on microscope slides following the standard methods [Lafontaine, Mikkola, 1987; Lafontaine, 2004]. The adults were photographed using a Nikon D90 SLR camera equipped with Nikkor AF Micro $60 \mathrm{~mm}$ lens and iPhone7. The genitalia preparations were photographed using a Canon

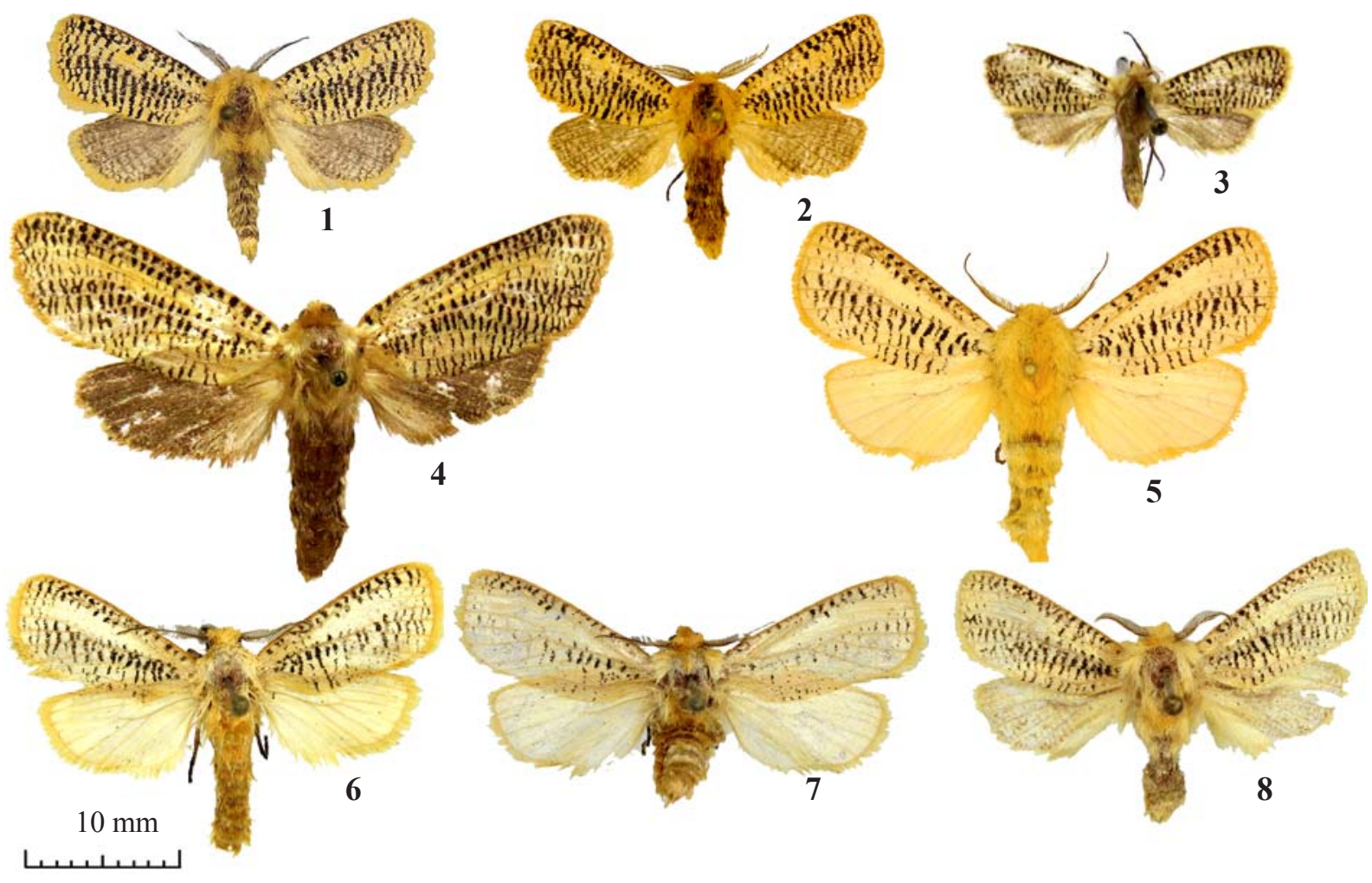

Figs 1-8. Azygophleps legraini species group: 1 - A. legraini, holotype, male (RMCA); 2 - A. legraini, male, Cameroon, North Region,

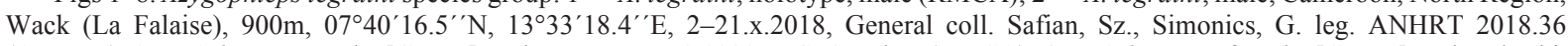
(ANHRT); 3 - A. legraini, male, [Congo], Lulua, Kapanga, 8.1933, F.G. Overlaet (RMCA); 4 - A. legraini, female, [Congo], Lubumbashi, 12.06.1934 (RMCA); 5 - A. adamsonae Yakovlev et László, sp.n., holotype, male (ANHRT); 6 - A. attenboroughi Yakovlev, Müller et Kravchenko, sp.n., holotype, male (MWM); 7 - A. attenboroughi Yakovlev, Müller et Kravchenko, sp.n., paratype, male (MWM); 8 Azygophleps pinheyi Yakovlev et László, sp.n., holotype, male (NHMZ).

Рис. 1-8. Группа видов Azygophleps legraini: 1 - A. legraini, голотип, самец (RMCA); 2 - A. legraini, самец, Сameroon, North Region, Wack (La Falaise), 900m, 0740'16.5”N, 13³3'18.4”E, 2-21.x.2018, General coll. Safian, Sz., Simonics, G. leg. ANHRT 2018.36 (ANHRT); 3 - A. legraini, самец, [Congo], Lulua, Kapanga, 8.1933, F.G. Overlaet (RMCA); 4 - A. legraini, caмка, [Congo], Lubumbashi, 12.06.1934 (RMCA); 5 - A. adamsonae Yakovlev et Lászly, sp.n., голотип, самец (ANHRT); 6 - A. attenboroughi Yakovlev, Müller et Kravchenko, sp.n., голотип, самец (MWM); 7 - A. attenboroughi Yakovlev, Müller et Kravchenko, sp.n., паратип, самец (MWM); 8 Azygophleps pinheyi Yakovlev et László, sp.n., голотип, самец (NHMZ). 
EOS 700D SLR camera mounted on a Wild M7A stereomicroscope and an Olympus DP74 camera attached to an Olympus SZX16 stereomicroscope.

Abbreviations

ANHRT - African Natural History Research Trust (Leominster, Great Britain),

NHMZ - Natural History Museum of Zimbabwe

(Bulawayo, Zimbabwe),

MWM - Museum Witt (Munich, Germany),

RMCA - Royal Museum of Central Africa (Tervuren, Belgium).

LG - Genitalia slide prepared by Gyula M. László

\section{Taxonomic part}

\section{Azygophleps adamsonae Yakovlev et László, sp.n.} Figs 5, 10, 13 .

MATERIAL. Holotype: $0^{7}$, "Cameroon, 900m, North Region,

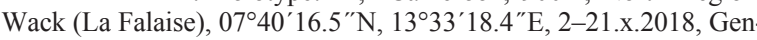
eral coll. Safian, Sz., Simonics, G. leg., ANHRT:2018.36"; unique number ANHRTUK 00076478; Gen. slide no.: LG 5186 (ANHRT).

DESCRIPTION. Length of forewing $14.5 \mathrm{~mm}$. Antenna bipectinate in basal three-quarters, filiform in apical quarter, half as long as length of forewing. Head, thorax and abdomen densely covered in lemon-yellow scales. Forewing relatively broad, pale yellow variegated by dense black transverse streaks throughout the whole surface of wing except in radial zone (from root to submarginal area) forming a distally slightly dilated creamy stripe; fringe lemon-yellow with some reddish shade. Hind wing creamy yellow without pattern, fringe lemon-yellow.

Male genitalia. Uncus short, robust, gradually narrowing from base to apex, triangular, apically rounded; gnathos arms very thin, short, unfused without medial plate of gnathos; valvae relatively narrow, leaf-shaped, costal margin almost straight, ventral margin straight in basal two-thirds, evenly arcuate in apical third; juxta robust, basally semicircular, with long lanceolate posterio-lateral processes, directed distally; saccus semicircular, wide; phallus robust, equal in length with valva, with long spindle-like carina process.

Female unknown.

DIAGNOSIS. The new species clearly differs from the closely related further species of the A. legraini species group by its larger size, absence of the hindwing pattern, and the straight costal and ventral margins of the valvae.

ETYMOLOGY. The new species is named after Friederike Victoria "Joy" Adamson (1910-1980), renowned naturalist, artist and author. Her book, Born Free, describes her experiences raising a lion cub named Elsa. Born Free was printed in several languages and also adapted into an Academy Award-winning movie.

\section{Azygophleps attenboroughi \\ Yakovlev, Müller et Kravchenko, sp.n.}

Figs 6-7, 11, 13.

MATERIAL. Holotype: $\sigma^{7}$, Southern Mali, 80 km SW Bamako, near Kineiroba, river Niger, $360 \mathrm{~m}$, October 2015, leg. Müller, Kravchenko, Traore, al. (MWM; GenPr MWM - 31.846).

Paratype: male, $80 \mathrm{~km} \mathrm{SW}$ Bamako, near Ourina forest, river Niger, 420 m, August 2015, leg. Müller, Kravchenko, Traore, al. (MWM)

DESCRIPTION. Length of forewing $12.5 \mathrm{~mm}$. Antenna half as long as the length of fore wing. Head, thorax and abdomen densely covered in lemon-yellow scales. Forewing narrow, pale yellow with dense blackish transverse streaks throughout the wing surface. Black streaks absent in radial zone (from root to submarginal area); fringe orange. Hindwing pale yellow without pattern, fringe orange.

Male genitalia. Uncus conspicuously short, robust, gradually narrowing from base to apex, apically triangular; gnathos arms very thin, short, unfused, without medial plate of gnathos; valvae relatively wide, leaf-shaped, costal margin almost straight, ventral margin evenly arcuate with a short depression in the medial third; juxta robust, basally semicircular, with long lanceolate posterio-lateral processes, directed caudad; saccus semicircular, wide; phallus robust, three-quarters as long as the valva, with long spindle-like carina process.

Female unknown.

DIAGNOSIS. The new species is distinguished from the other taxa of the $A$. legraini species group by the absence of hindwing pattern; from its closest congener $A$. adamsonae by the somewhat darker, more contrasting fringe of wings, the triangular apex of the uncus (that is broadly rounded in $A$. adamsonae), and the short depression in the medium third of the valval ventral margin (that is straight in its congener)

ETYMOLOGY. The new species is dedicated to Sir David Frederick Attenborough, world-famous English broadcaster and natural historian. He is best known for writing and presenting with the BBC Natural History Unit, and the nine natural history documentary series forming the Life collection providing a comprehensive overview of animal and plant life on Earth.

\section{Azygophleps pinheyi Yakovlev et László, sp.n.} Figs 8, 12, 13

MATERIAL. Holotype, $\sigma^{\top}$, Muquitixe $\left[10.416667^{\circ} \mathrm{S} / 14.95^{\circ} \mathrm{E}\right]$, Angola, 23.iv.1971, P. de Carvalho (NHMZ).

DESCRIPTION. Length of forewing $12 \mathrm{~mm}$. Antenna half as long as the length of fore wing. Head, thorax and abdomen densely covered in lemon-yellow scales. Fore wing relatively wide, lemon-yellow with dense blackish transverse streaks throughout the wing surface except in the radial zone (from root to submarginal area); fringe lemon-yellow with a slight brownish shade. Hindwing pale yellow with diffuse reticulated pattern of thin pale grey streaks throughout the wing, fringe lemon-yellow.

Male genitalia. Uncus very short, robust, gradually narrowing from base to apex, apically rounded; gnathos arms very thin, short, unfused, without medial plate of gnathos; valvae relatively broad, leaf-shaped, costal margin evenly arcuate, slightly convex, ventral margin with a short, broad depression in its proximal third; juxta robust, basally semicircular, with long lanceolate posterio-lateral processes, directed caudad; saccus semicircular, broad; phallus robust, threequarters as long as the length of valva, with long spindle-like carinal process.

Female unknown.

DIAGNOSIS. The new species clearly differs from the closely related species of the $A$. legraini species group by its pale, diffuse reticulated pattern of the hindwing, the very short uncus, the arcuate costal valval margin and the presence of a shallow depression on the basal third of the ventral margin of the valve.

ETYMOLOGY. The new species is named after Elliot Charles Gordon Pinhey (1910-1999), renowned entomologist who spent most of his life in Africa studying Lepidoptera and Odonata. He joined the Transvaal Museum in Pretoria as assistant professional officer in entomology and later became the Museum's Odonata specialist. He had been working in the Coryndon Museum 
in Nairobi from 1949 to 1955 under Dr. LSB Leakey, during this period he was able to collect insects extensively in eastern and central Africa, developing an interest also in Orthoptera and Hemiptera. Pinhey was invited in 1955 to take up the position of the Keeper of Invertebrate
Zoology at the National Museum in Bulawayo, Zimbabwe. He was awarded a D.Sc. title by the University of London in 1962 for his publications in entomology. He served as the President of the Entomological Society of Southern Africa from 1974 to 1975.

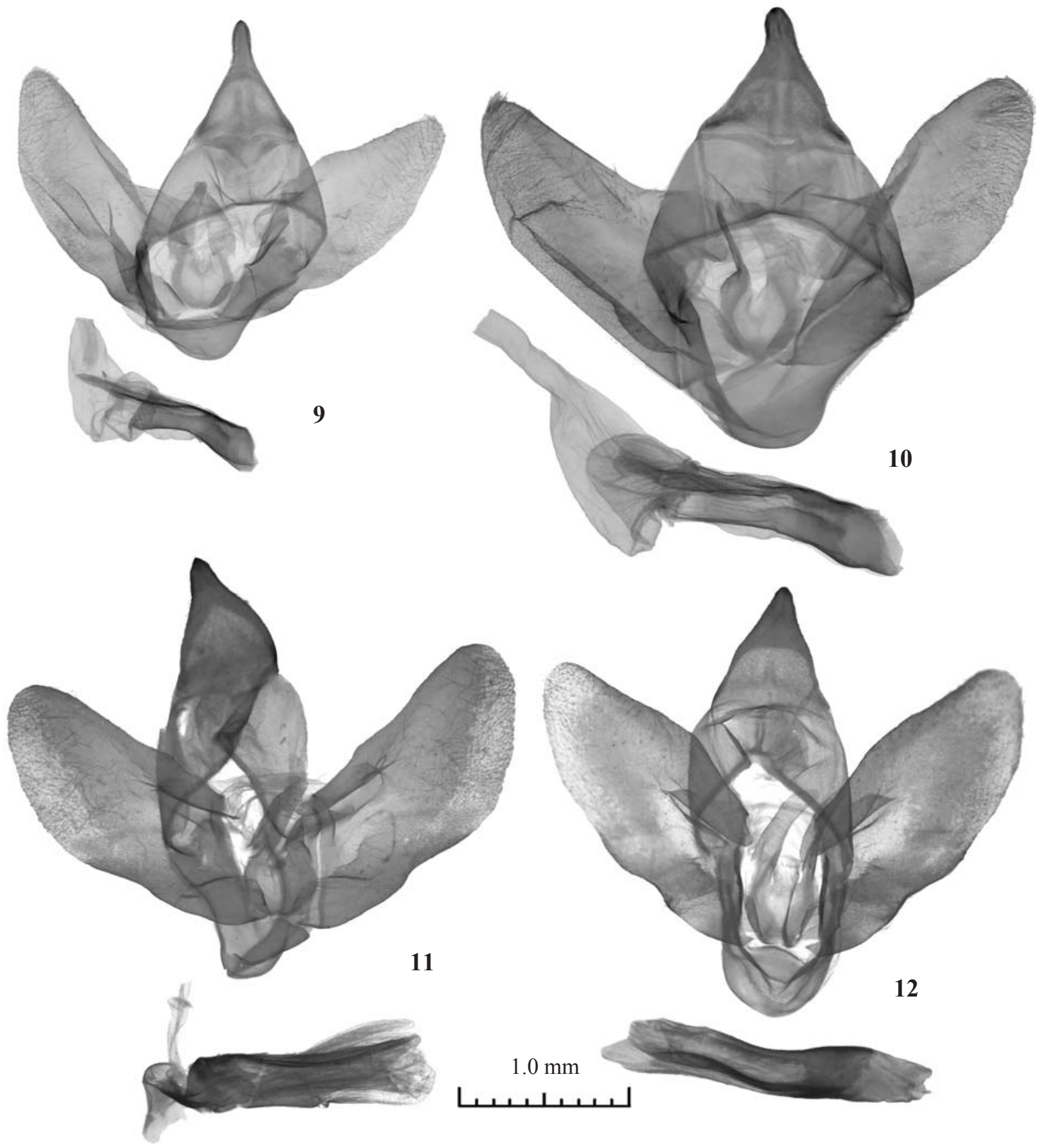

Figs 9-12. Azygophleps legraini species group, male genitalia: $9-$ A. legraini, Cameroon, North Region, Wack (La Falaise), 900m, 07 $7^{\circ} 0^{\prime} 16.5^{\prime \prime} \mathrm{N}, 13^{\circ} 33^{\prime} 18.4^{\prime \prime} \mathrm{E}, 2-21 . x .2018$, General coll. Safian, Sz., Simonics, G. leg., Gen. slide no.: LG 5187 (ANHRT); $10-A$. adamsonae Yakovlev et László, sp.n., holotype, Gen. slide no.: LG 5186 (ANHRT); 11 - A. attenboroughi Yakovlev, Müller et Kravchenko, sp.n., holotype, slide Genitalpräparat Heterocera Nr. 31.846 (MWM); 12 - Azygophleps pinheyi Yakovlev et László, sp.n., holotype, slide NMZ-1 (NHMZ).

Рис. 9-12. Группа видов Azygophleps legraini, гениталии самцов: $9-$ A. legraini, Cameroon, North Region, Wack (La Falaise), 900m, 07040'16.5"N, 133' 18.4"E, 2-21.x.2018, General coll. Safian, Sz., Simonics, G. leg., Gen. slide no.: LG 5187 (ANHRT); $10-$ A. adamsonae Yakovlev et László, sp.n., голотип, Gen. slide no.: LG-5186 (ANHRT); $11-A$. attenboroughi Yakovlev, Müller et Kravchenko, sp.n., голотип, slide Genitalprдраrat Heterocera Nr. 31.846 (MWM); 12 - Azygophleps pinheyi Yakovlev et László, sp.n., голотип, slide NMZ-1 (NHMZ). 
Species content of the

Azygophleps legraini Yakovlev et Saldaitis, 2011 species group

Azygophleps adamsonae Yakovlev et László, sp.n. TYPE MATERIAL: holotype male in coll. ANHRT, examined. TYPE LOCALITY: Cameroon, North Region, Wack (La Falaise).

DISTRIBUTION: Cameroon, North Region.

Azygophleps attenboroughi Yakovlev, Müller et Kravchenko, sp.n.

TYPE MATERIAL: holotype male in coll. MWM, examined.

TYPE LOCALITY: Southern Mali, 80 km SW Bamako, near Kineiroba, river Niger.

DISTRIBUTION: Southern Mali.

Azygophleps legraini Yakovlev et Saldaitis, 2011

Yakovlev, Saldaitis, 2011: 86

TYPE MATERIAL: holotype male in coll. RMCA, examined.

TYPE LOCALITY: Cameroun, Adamaoua, nr. Ngaoundéré, Ngaoundaba.

ADDITION MATERIAL: 1 б', [Congo], Lulua, Ka- panga, 8.1933, F.G. Overlaet (RMCA); 1 \%, [Congo], Lubumbashi, 12.06.1934 (RMCA); $1 O^{T}$, [Congo], Katanga, Zilo, 3.1968, Rec. V. Allard (RMCA); 1 $\sigma^{7}$, Congo Belge, Lusinga $1760 \mathrm{~m}, 31.03 .1947$, Mis. G.F. de Witte (RMCA); $3 \sigma^{7} \sigma^{7}$, Congo Belge, P.N.G., Miss H. De Saeger, 3.12.1951, Rec. H. De Saeger (RMCA); $3 \sigma^{7} \sigma^{7}$, [Congo], Kivu, Mweza, 27.03.1957, R.P. de Caters (RMCA); 1 \%", Cameroon, North Region, Wack (La Falaise), 900m, $07^{\circ} 40^{\prime} 16.5^{\prime \prime} \mathrm{N}, 13^{\circ} 33^{\prime} 18.4^{\prime \prime} \mathrm{E}, 2-21 . x .2018$, General coll. Safian, Sz., Simonics, G. leg., ANHRT 2018.36, unique number ANHRTUK 00057994, gen. slide No.: LG 5187 (ANHRT).

DIAGNOSIS. The species clearly differs from the closely related other taxa of the A. legraini species group by its relatively small size, conspicuously dense black pattern consisting of short streaks on the hind wing, and the relatively long and narrow uncus.

DISTRIBUTION: Cameroon, Democratic Republic of the Congo.

Azygophleps pinheyi Yakovlev et László, sp.n.

TYPE MATERIAL: holotype male in coll. NHMZ, examined.

TYPE LOCALITY: Muquitixe $\left[10.416667^{\circ} \mathrm{S} / 14.95^{\circ} \mathrm{E}\right]$, Angola.

DISTRIBUTION: Angola.

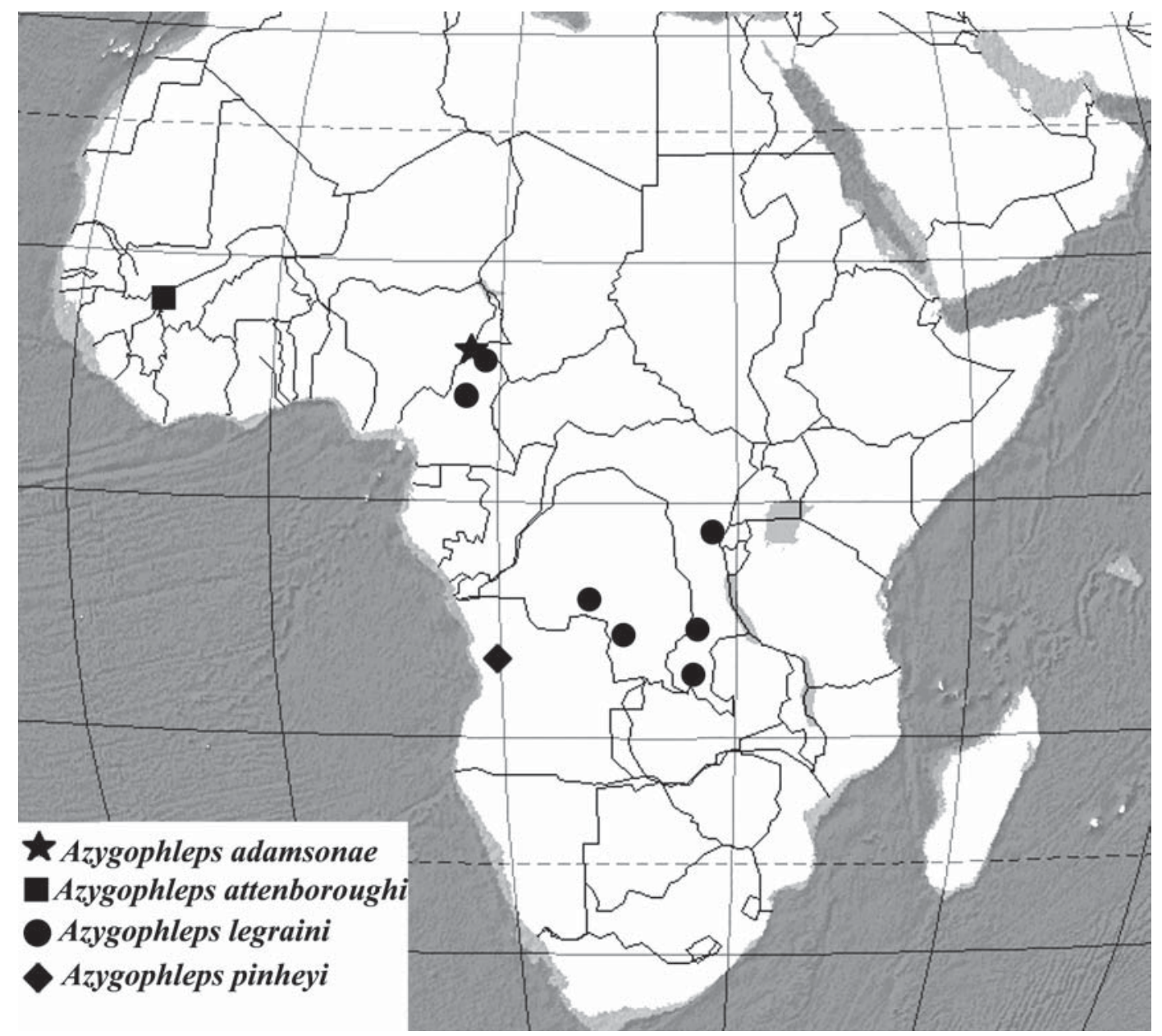

Fig. 13. Distributional map of Azygophleps legraini species group.

Рис. 13. Карта распространения группы видов Azygophleps legraini. 


\section{Discussion}

The diverse and widespread Cossidae genus $A z y$ gophleps is in need of a thorough revision. The A. legraini species group is distributed in western Africa from South Mali to Angola. The West African fauna of Cossidae is very specific including a number of endemic and subendemic genera: Gumilevia Yakovlev, 2011 (type species Gumilevia zhiraph Yakovlev, 2011), Assegai Yakovlev, 2006 (type species Assegaj clenchi Yakovlev, 2006), Mirocossus Schoorl, 1990 (type species Brachylia badiala Fletcher, 1968), Politzariella Yakovlev, 2011 (type species Politzariella pantherina Yakovlev, 2011), Holcoceroides Strand, [1913] (type species Holcoceroides ferrugineotincta Strand, [1913]), Geraldocossus Yakovlev et Sáfián, 2016 (type species Geraldocossus durrelli Yakovlev et Sáfián, 2016), Eburgemellus Schoorl, 1990 (type species Xyleutes geminatus Gaede, 1930), Pseudozeuzera Schoorl, 1990 (type species Duomitus biatra Hampson, 1910) and Acosma Yakovlev, 2011 (Type species Acosma gurkoi Yakovlev, 2011). Majority of the species seems to be rather uncommon as the low number of available collection specimens indicates. The differences expressed by the characters of the apparently simplified genitalia are rather subtle, but allowing reliable species delimitations.

Acknowledgements. The senior author is indebted to $\mathrm{Mr}$ Richard Smith (ANHRT, Leominster), Dr. Moira Fitzpatrick (NHMZ, Bulawayo), and Drs Didier Van den Spiegel, Alice Buset, Jurate and Willy De Prins (RMCA, Tervuren) for the opportunity to study the Cossidae material of the collections under their care; in addition to Dr Thomas J. Witt† (MWM) for his long term, irreplaceable assistance provided during examining of the Cossidae material in the Museum Witt. Our special thanks go to Dr. Anna K. Ustjuzhanina (Tomsk, Russia) for the linguistic corrections of the manuscript.

Competing interests. The authors declare no competing interests.

\section{References}

Arora G.S. 1976. A taxonomic revision of the Indian species of the family Cossidae (Lepidoptera) // Records of the Zoological Survey of India. Vol.69. No.1-4. P.1-160.

Daniel F. 1963. Ein Beitrag zur Spinner- und Schwamer-fauna des Iran und Afghanistans // Zeitschrift der Wiener Entomologischen Gesellschaft. Vol.48. P.145-155.

Daniel F. 1964. Cossidae aus Afganistan (Lep.) // Opuscula Zoologica. Vol.77. P.1-8.

Hua B., Chou I., Fang D., Chen S. 1990. The cossid fauna of China (Lepidoptera, Cossidae). Yangling, Shaanxi, 147 pp.

Lafontaine J.D. 2004. Noctuoidea, Noctuidae (part), Noctuinae (part-Agrotini) // Hodges R.W. (ed.). The Moths of America North of Mexico. Fasc.27.1. Washington: The Wedge Entomological Research Foundation. 385 pp.

Lafontaine J.D., Mikkola K. 1987. Lock-and-key system in the inner genitalia of Noctuidae (Lepidoptera) as taxonomic character // Entomologiske Meddelelse. Vol.55. P.161-167.

Mey W. 2015. Revision of the genus Arctiocossus Felder, 1874 and allied genera (Lepidoptera: Cossidae: Cossinae) // Annals of the Ditsong National Museum of Natural History. Vol.5. P.28-55.

Mey W. 2016. A taxonomic and faunistic study of the Cossidae of southwestern Africa (Lepidoptera: Cossoidea) // Annals of the Ditsong National Museum of Natural History. Vol.6. P.146-198.

Mey W. 2017. Corrections and additions to the Cossidae of southern Africa (Lepidoptera: Cossoidea) // Entomologische Zeitschrift. Vol.127. No.4. P.218-222.
Mey W. 2019. On the identity of Azygophleps asylas (Cramer, 1779 [1777]) in southern Africa and descriptions of related species (Lepidoptera, Cossidae) // Annals of the Ditsong National $\mathrm{Mu}-$ seum of Natural History. Vol.8. P.43-58.

Nieukerken van E.J., Kaila L., Kitching I.J., Kristensen N.P., Lees D. C., Minet J., Mitter C., Mutanen M., Regier J.C., Simonsen T.J., Wahlberg N., Yen S.-H., Zahiri R., Adamski D., Baixeras J., Bartsch D., Bengtsson B.A., Brown J.W., Bucheli S.R., Davis D.R., De Prins J., De Prins W., Epstein M.E., Gentili-Poole P., Gielis C., Hättenschwiler P., Hausmann A., Holloway J.D., Kallies A., Karsholt O., Kawahara A., Koster J.C., Kozlov M.V., Lafontaine J.D., Lamas G., Landry J.-F., Lee S., Nuss M., Park K.T., Penz C., Rota J., Schmidt B.C., Schintlmeister A., Sohn J.C., Solis M.A., Tarmann G.M., Warren A.D., Weller S., Yakovlev R.V., Zolotuhin V.V., Zwick A. 2011. Order Lepidoptera Linnaeus, 1758 // Zootaxa. Vol.3148. P.212-221.

Schoorl J.W. 1990. A phylogenetic study on Cossidae (Lepidoptera: Ditrysia) based on external adult morphology // Zoologische Verhandelingen. Vol.263. P.1-295.

Yakovlev R.V. 2011. Catalogue of the Family Cossidae of the Old World (Lepidoptera) // Neue Entomologische Nachrichten. Bd.66. S.1-130.

Yakovlev R.V. 2014. Cossidae (Lepidoptera) of Zambia // Check List. Vol.10. No.4. P.724-728. DOI: 10.15560/10.4.724

Yakovlev R.V. 2019. Review of the Genus Acosma Yakovlev, 2011 (Lepidoptera, Cossidae) // Far Eastern Entomologist. No.386. P.1-7. DOI: $10.25221 /$ fee. 386.1

Yakovlev R.V., Dubatolov V.V. 2013. Distribution of CarpenterMoths in Palaearctic Desert // Zoologicheskii Zhurnal. Vol.92. No.6. P.682-694. DOI: 10.7868/S0044513413040193

Yakovlev R.V., Lenz J. 2013. On the Fauna of Cossidae (Lepidoptera) of Zimbabwe with description of a new species // Zootaxa. Vol.3718. No.4. P.387-397. DOI: 10.11646/zootaxa. 3718.4 .8

Yakovlev R.V., Murphy R.J. 2013. The Cossidae (Lepidoptera) of Malawi with descriptions of two new species // Zootaxa. Vol.3709. No.4. P.371-393. DOI: 10.11646/zootaxa.3709.4.5

Yakovlev R.V., Pljustch I.G., Skrylnik Yu., Pak O., Witt Th. 2015. The Cossidae (Lepidoptera) of Afghanistan with description of three new species and special notes on the fauna of Bande-Amir National Park // Zootaxa. Vol.3990. No.1. P.41-72. DOI: 10. 11646/zootaxa.3990.1.3

Yakovlev R.V., Sokolova G.G., Witt Th. 2018. Cecryphalini Yakovlev et Witt, trib. n. - new tribe of Carpenter Moths (Lepidoptera: Cossidae: Zeuzerinae) // Russian Entomological Journal. Vol.27. No.4. P.415-424. DOI: 10.15298/rusentj.27.4.09

Yakovlev R.V., Sulak H., Witt Th.J. 2019. Preliminary list of Cossidae sensu str. (Lepidoptera, Cossoidea: Cossidae: Cossinae, Zeuzerinae) of the Republic of Angola with description of a new Strigocossus species // Zootaxa. Vol.4586. No.3. P.445460. DOI: $10.11646 /$ zootaxa 4586.3 .3

Yakovlev R.V., Witt Th.J. 2016a. Carpenter-Moths (Lepidoptera: Cossidae) of Swaziland, South Africa // Far Eastern Entomologist. No.311. P.9-12.

Yakovlev R.V., Witt Th. 2016b. Azygophleps brehmi Yakovlev et Witt, sp.n. - a new Carpenter-Moth (Lepidoptera, Cossidae) from Ethiopia // Russian Entomological Journal. Vol.25. No.1. P.71-73.

Yakovlev R.V., Witt Th.J. 2017a. Redescription of the Genus Paralophonotus Schoorl, 1990 based on the morphology of male genitalia (Lepidoptera: Cossidae) // SHILAP Revista de lepidopterología. Vol.45. No.180. P.665-668.

Yakovlev R.V., Witt Th.J. 2017b. Four new species of Azygophleps Hampson, 1892 (Lepidoptera, Cossidae, Zeuzerinae) from Africa // Zootaxa. Vol.4303. No.3. P.437-444. DOI: 10.11646/ zootaxa.4303.3.9

Yakovlev R.V., Witt Th. 2018a. Redescription and Catalogue of little known genus Pseudozeuzera Schoorl, 1990 (Lepidoptera: Cossidae) // Russian Entomological Journal. Vol.27. No.3. P.289-292.

Yakovlev R.V., Witt T.J. 2018b. Redescription of the genus Alophonotus Schoorl, 1990 based on the morphology of male and female genitalia (Lepidoptera: Cossidae) // SHILAP Revista de lepidopterología. Vol.46. No.184. P.647-652.

Yakovlev R.V., Witt T.J. 2018c. Redescription of the little known genus Eburgemellus Schoorl, 1990 (Lepidoptera: Cossidae) // Far Eastern Entomologist. Vol.364. P.1-5. DOI: 10.25221/fee.364.1 